\title{
ХРИШЋАНСКО ВАСПИТАҢЕ И МОДЕРНА ПЕДАГОШКА МИСАО
}

\author{
Ивица Живковић ${ }^{1}$ \\ Центар за црквене студије, Ниш
}

\begin{abstract}
Ancmpaкm: Хришћанска педагогија утемељена је на нарочитом педагошком приступу, које у свим историјским периодима представља више од неког могућег новог учења, нове педагошке теорије или система педагошких схватања у свету. У овом раду приказујемо хришћанско васпитање кроз неколико најопштијих принципа, од којих су најважнији: полазиште вере у Бога, специфичан однос љубави према детету и свесност о људском греху. У даљем току рада истражујемо мишљење релевантних истраживача који су тврдили да је значај приписан детету у историји педагошке мисли везан за дубље продирање хришћанске религије у обичаје и схватања западног света. Утицај хришћанства је видљив и у еманципаторским тенденцијама класика педагошке мисли, пре свих у ставовима Марије Монтесори, чије тумачење Христових речи о деци наводимо као један од највећих изазова савременом виђењу детета. Положај детета и одраслог у савременом свету намеће одређене дилеме, у чијем разрешавању хришћанска педагогија може да понуди важан допринос.
\end{abstract}

Кључне речи: хришћанство, дете, васпитање, еманщипаторске тенденције, постмодерно стане

\section{1. Хришћанско васпитање и педагогија}

Хришћанска педагогија је учење о васпитању сагласно богооткривеној хришћанској вери. Хришћанско васпитање је васпитање хришћана, хришћански живот посматран кроз призму његових педагошких учинака, а хришћанска педагогија је суд о васпитању са хришћанског становишта. Хришћанство се јавило као потпуно нов начин живота у историји света, заснован на новом, другачијем односу људи према Богу, ближњима и самима себи. Стога је и хришћанска педагогија утемељена на нарочитом педагошком приступу, које у свим историјским периодима представља више од неког могућег новог учења, нове педагошке теорије или система педагошких схватања у свету.

Господ Исус Христос је радикално подвукао неопходност разликовања између божанског становишта и људских судова (види: Мт. 16. 21-25). Ово

\footnotetext{
${ }^{1}$ ivica.zzivkovic@gmail.com
} 
разликовање мора доћи до изражаја и по питању хришћанске педагогије: шта је у хришћанским односима одраслих са децом божанско а шта људско (Сандо и Живковић, 2014: 11). Подметање људских мишљења и ставова на место откривене Божје воље, чак и када се оно ненамерно дешава, осим што представља напад на слободу човека, доводи у питање сам хришћански идентитет нечијег (педагошког) става. Када је реч о разумевању хришћанске педагогије, треба се држати шире перспективе. Циљ хришћанског васпитања треба да буде увођење људи у живот будућег века, који се у Еванђељу проповеда као Царство Божје. Као такво, оно не занемарује ствари и догађања у животу овога века, већ им даје нешто конкретнији значај који хришћани сматрају одговарајућим и правим. Сматра се да све што човек мисли, говори или чини у животу има последице по његово вечно постојање. Божја љубав која се открива у светотајинском и духовном животу цркве чини човека целовито слободним и целовито одговорним бићем. Ова слобода и одговорност нису некакве стечене привилегије на које би се неко могао позивати или се борити за њих. Оне спадају у област тајне духовног искуства у којем човек доживотно узраста.

О добро васпитаном појединцу у хришћанској педагогији не може се говорити само у оквирима аутономног људског бића које поштује одређене принципе и идеје о духовности. Хришћански васпитано дете је личност на страни Бога, неко ко је у заједници са Богом. Вера у Бога омогућава потпуно другачију, онострану, нову позицију човека и ново схватање васпитаности и васпитања. Природно је, како пише Амфилохије Радовић, да васпитни идеал и циљеви васпитања, као и методи образовања, зависе од основних претпоставки на којима се утемељује одређена култура. Као и све остало, и педагошка мисао зависи од схватања света и човека и њиховог коначног циља (Амфилохије, 1993: 25).

\section{2. Најопштији принципи хришћанског васпитања}

Хришћанско васпитање могло би се укратко приказати кроз неколико најопштијих принципа, од којих су најважнији: полазиште вере у Бога, специфичан однос љубави према детету и свесност о људском греху. Одрасли и деца, посматрано са хришћанског становишта, никада се не налазе у неком „бестежинском стању“ - важно је увек имати на уму какав однос једно конкретно дете сада има са Богом, затим са својим родитељима (и/или другим одраслим људима, старијима), као и однос који оно тренутно заузима према свету. Ови односи су динамичне природе и подложни су сталној промени. Такође, важан је и однос какав родитељ или одрасла особа која је у контакту са дететом има према њему, а какав са осталим учесницима из непосредног окружења, какав је његов или њен однос према свету, као и то какав је однос који има са Богом. Овај на крају поменути чинилац, однос према Богу, никако није и последњи по важности у православном васпитању. Напротив, то је оно по чему је хришћанско васпитање нарочито, то јест специфично у односу на неке друге теорије и правце педагогије у свету. 
Веровати у Бога не значи изјашњавати се о томе или говорити другима да Бог постоји. То значи у свом животу стављати Бога на прво место у односу на све друго, па и у односу на себе саме. Људи могу с правом да мисле и да тврде да они васпитавају своју децу. Али оно што је важније и истинитије од тога јесте чињеница да је Бог тај који штити, спашава, милује и чува њихову децу и њих. У односу одраслих са децом важно је имати у виду њега, који свиме руководи и све чува, па тек онда себе и своје намере. У хришћанском васпитању није реч само о томе шта људи раде са својом децом, већ пре свега шта чине са собом, као родитељима и одраслим људима који са децом живе и који утичу на њих својим примером. Ако изгубе из вида свој однос са Богом, да се њихов утицај на децу увек догађа пред њим, и ако нису свесни да је Бог тај који васпитава њихову децу и њих, те ако се превише уздају у себе и своје намере, своју људску памет и своје људске снаге, онда су у опасности да се испрече на путу између своје деце и Бога. Оно што је још опасније, то је да родитељи као одрасли људи често сами себе стављају на место Бога у животу њихове деце. То се дешава када они као људи мисле да су увек у праву, да су непогрешиви, да знају шта је за њихово дете најбоље и да су њихова упутства детету најважнија.

Родитељи, наставници и васпитачи који не желе да ставе себе на место Бога, или не желе да заклоне пут између деце и Бога, не уздају се у себе и у своје васпитне намере, већ се за све што је добро у животу њихове деце и себе самих обраћају Богу. Позив на молитву у хришћанском васпитању није само одјек неких старих времена. Тај позив постоји и у савременим размишљањима о васпитању у животу хришћанских породица. Молитва је прва и превасходна делатност родитеља у васпитању њихове деце (Сандо и Живковић, 2014: 159). То је дело у којем се огледа стварна, заокружена, потпуна љубав одраслих према деци. Смисао хришћанског васпитања лежи у чињеници да постоји узајамни однос између васпитања и Божјег промисла о спасењу људи. Молитвено осећање благодарности проистиче из сазнања хришћана да је њихов живот, живот њихове деце, као и све што имају у животу и у односу са њима - Божји дар. Захвални су Богу на својој деци и на свему добром што им даје. Исто тако прихватају Божју вољу и у тешкоћама, у проблемима са којима се суочавају, а чији им смисао још увек није јасан. Захвалност је, према хришћанској етици, најузвишеније осећање и најпотпунији увид у истину о властитом животу. Исто тако треба износити Богу и сва друга осећања, било добра или тешка. Све своје проблеме, тешкоће и недоумице, страхове и бриге, хришћани поверавају Богу. То важи и за оне ситуације када мисле о својој деци.

Други општи принцип хришћанске педагогије тиче се односа љубави. Прва и најважнија Христова заповест јесте заповест љубави. То важи у свим односима које хришћани негују између себе, па и у односима са децом. Прва тема хришћанске педагогије није васпитавање деце, већ је то љубав према деци. Љубав према детету, а не васпитање, треба да буде прва помисао на помен детета - као што и прва помисао на помен човека не треба да буде шта радити с њим и како постићи некакве циљеве и намере, већ како изградити односе истините хришћанске љубави. Истинска хришћанска љубав није нечије 
духовно постигнуће или резултат васпитних намера. Пре би се могло рећи да хришћанско васпитање (као и све друго што постоји у животу хришћана) треба да проистиче из божанске љубави која се јавља људском роду.

Хришћанска љубав је по свом пореклу и значењу исто што и Христова љубав, откривена, завештана и дарована његовим ученицима. Као што Omau љуби њега и Он љуби нас и ми треба да останемо у његовој љубави (види: Јн 15.9). То је једина нова Христова заповест, свеодређујући садржај хришћанског живота и знак по којем се препознаје да ли је неко Христов ученик (Живковић, 2011: 54-55). Љубав је пуноћа закона, свега онога што треба да чинимо. Као таква, она одређује и то какво ће бити нечије хришћанско васпитање. Љубав хришћана према деци не потиче из родитељског нагона, она не настаје самим тим што неко има децу, нити је она одређена идејама и замислима о добром детету. Хришћани су позвани да прихвате своје дете као што Бог прихвата њих, дајући му слободу и љубав као што Бог даје њима. Православно васпитање одликује се потпуним уважавањем и прихватањем боголике душе детета.

Једино поуздано средство у васпитању је сама личност одрасле особе. Свако васпитава децу на основу онога што јесте. Никакве методе, поступци и идеје не могу да надокнаде оно што родитељ може и треба да буде. Васпитање настаје у чину отварања, узајамног давања душе родитеља и душе детета у постојећем односу љубави. Зато васпитач (родитељ, наставник, свештеник) - било да има намеру да васпитава или не - представља пример упркос себи самом, чак и онда када није тога свестан. Хришћанско васпитање не догађа се у наметању сопствених виђења, већ када искуство одраслог и искуство детета дођу у најдубљи и најискренији додир пред Богом, када једни другима сведоче Христа. У стварном односу љубави, одрасли охрабрују дете да слободно приступи живом искуству истине живота, препуштају му одговорност у томе и нуде му своју подршку (одобравање, благослов) и своје присуство.

Трећи општи принцип хришћанског васпитања односи се на свесност о греху који постоји у свету и животу свих људи. Основна мисао европског хуманизма и европске културе гласи: човек је по природи добар и све пројаве његових природних нагона су добре. Зло се јавља само онда када тим природним нагонима стављамо забране. У западном свету личност људског бића уздигнута је на ниво божанства. У овоме треба сагледавати и један од најкрупнијих чинилаца размимоилажења између савременог хуманистичког васпитања у свету и хришћанске педагогије. Хришћанска педагогија зна и за другу, тамну, немоћну страну човека, за оне покрете које грех уноси у душу. Васпитање које нема у виду трагично стање човека и његове природе - не може открити ни пуноћу људског лика. Тако поред позитивне стране, усавршавања личности, у православном васпитању постоји и она негативна страна, спасавање личности од греха који је упропаштава (Амфилохије, 1993: 54).

Веома је битан метод тог спасавања, како неко чува своју децу од греха, како предупређује грех код детета. У хришћанском предању се сматра да само пажња на себи, служење Богу и молитвена сабраност могу да растерају мрак незнања и маглу прегрешења који потичу из греховног искуства. Човеков ,рад 
на себи“ уз поштовање Божјих заповести као принципа живота, хришћанским језиком назива се подвиг. То је живот достојан човека и детета. Узак и тегобан пут подвига временом прераста у благ јарам и лако бреме хришћанског духовног живота, а плач због греха добија своју утеху од Спаситеља, радост и мир од Господа. То даје прилику православним хришћанима да понуде своје одговоре на недоумице са којима се бори савремено васпитање у свету. Људи у свету до дан-данас нису изашли на крај са питањима: да ли је детињство само по себи добро или зло, да ли је дете већ сада добро, или ће оно постати добро тек када одрасте, када буде васпитано. Новозаветни еванђелски одговор гласи: дете је заиста нешто добро, оно је увек неко кога треба прихватити (примити - Мт. 18.5). Његова душа поседује вредност пред Богом, духовно достојанство једнако као и личност одраслог, ако не и веће. „Бити као деца, јер је таквих Царство небеско“ један је од еванђелских позива који је упућен Христовим ученицима и свим људима света.

Друга консеквенца овог принципа јесте то да људи треба да знају да нису у свему добри, да њихово васпитање није увек добро. Постоји његова тамна страна, у којој долази до изражаја слабост и грех одраслих - родитеља, свештеника, наставника и васпитача. Стога у хришћанском васпитању треба да важи један битан обзир: размишљати о тамној страни својих намера, чувајући децу од себе, од греха који се испољава при васпитним намерама одраслих. Комуницирање прародитељског греха, преношење греха од старијих на млађе, представља сталну опасност у педагошком односу. То треба да буде предмет сталног самопреиспитивања хришћана и свих људи света.

\section{3. Значај хришћанства у историји педагошке мисли}

У својој гласовитој књизи Векови детињства анализом различитих историјских извора (слика, књижевних дела, правних норми, језика), Аријес је показао да је до открића детета као бића посебне врсте долазило постепено до 17. века. У то време јавља се „нова осећајност“, која признаје посебан значај нејаком бићу детета. Значај који је дете задобило, како тврди Аријес, извесно је везан за дубље продирање хришћанске религије у обичаје и схватања западног света (Arijes, 1989: 69-70). Хришћанство је такође, по мишљењу Аријеса, формирало најважније револуционарне мислиоце о деци - Коменског (17. век), Русоа (18. век) и Монтесори (почетак 20. века).

Религиозно формиран појединац у стара времена (можда чак до половине 20. века) друкчије се односио према цркви и хришћанским празницима од човека (детета) у данашњем секуларизованом свету оптерећеном нихилизмом и хуманистичким идеалима. Примена основног хришћанског постулата о послушности на свакодневне односе са децом уздигло је дисциплиновање и кажњавање на највиши пијадестал. „Ко се понизи као дете“, стоји у Светом писму, „највећи је у Царству небеском“ (Мт. 18. 4). Међутим, понизност се у психологији сматра осећањем мање вредности, инфериорности према други- 
ма. Постоји такође људска потреба за доминацијом којом се могу објаснити у великој мери односи одраслих и деце, или „васпитање“. То је потреба да се буде изнад других, да се има моћ да се на друге утиче, да се њихово понашање контролише и да се њима влада. Кад настојимо да разумемо хришћански смисао послушности и слободе, суочавамо се са особеним значењем ових појмова у Светом писму. Притом треба имати у виду разлику која се прави између „мудрости људске“ и „силе Божје“ (1 Кор. 2. 5). Суптилније од психолога сведочи апостол Јован: „Љубљени, ако нас срце наше не осуђује, слободу имамо пред Богом“(1 Јн 3. 21).

Иринеј Буловић набраја класична светоотачка тумачења Христових речи о деци, почев од Кирила Александријског, по којем је дете „симбол незлобивости“, преко Блаженог Теофилакта Охридског, да „Царство небеско представља наслеђе оних који својом вољом стекоше безазленост и смерност коју деца природно поседују“ и Јевтимија Зигавина и других тумача који истичу ,једноставност и поверљивост детета, као и његову потребу за љубављу и нежношћу“, до оца Јустина Поповића, који запажа да су деца мали анђели у људском телу, да свако дете представља „парче неба на земљи, парче небеске истине, парче небеске правде, парче небеске бестрасности“, те да управо захваљујући тој својој чистоти деца, самим тим што су деца, поседују Царство небеско у својим незлобивим душицама. Он тврди да Господ Исус Христос својим Еванђељем доноси прави преокрет у васпитавању деце и немали преокрет у васпитавању одраслих. Заиста је посреди најкоренитија васпитно-просветна револуција откако је света и века (Буловић, 1984: 111-113).

Ерих Фром препознаје у Христовим речима указивање на целовитост дететовог доживљаја света. Према Фрому, морамо поново постати деца како бисмо искусили неотуђено, стваралачко поимање света. Марија Монтесори тумачи Христове речи педагошки, а Фром психолошки. Коментаришући у својој књизи Тајна детиюства Христове речи „Обратите се и будите као деца“ (Мт. 18. 3), Монтесори је закључила да су одрасли слепи јер раде супротно: себе постављају за узор деци. Још вели ова славна жена, лекар и педагог, да погрешан однос према деци потиче из „мистерије људске душе“, онога што се код Фројда и Јунга зове „несвесно“, а што се у педагогији третира као имплицитна филозофија, ставови и вредности. Исидор Граорац тврди да је освешћивање „неизлечивог слепила одраслих“, тог „универзалног феномена старог колико и само човечанство“, „мистерије људске душе“, спречила патријархална и педагошка свест (Граорац, 2017: 154).

Уобичајено је мишљење о традиционалној, патријархалној породици, како пише Граорац, да у њој влада отац (најстарији мушкарац), да су жене и поготово деца у подређеном положају. Међутим, пажње је вредан увид Светозара Марковића о снази породичне љубави и општинске узајамности у патријархалном друштву. Он је писао да се потчињеност у породицама веома разликује од бирократске и уопште државне потчињености. Исто тако, Жарко Требјешанин тврди да ауторитет родитеља почива на снажној привржености и љубави детета према њима. Сеоска породица је функционисала као радна заједница. Животни 
радни круг на селу је непрекинут од сасвим раног детињства до пред смрт. Поред тога, у стара времена игра је подједнако припадала и деци и одраслима. И за једне и за друге представљала је важан сегмент живота (Граорац, 2017: 149).

Како год било, деца и детињство су невидљиви у историји хришћанства и хришћанских цркава, не помињу се у културној историји Срба а ни других народа, упркос истакнутом месту и дубоком значењу које им приписују Стари и Нови завет. Будући да је свет детињства неодвојиви део начина живота и културе сваког народа и човечанства у целини, у прошлости - као и данас - ако се мисли на децу, може се говорити о невидљивој присутности. Одрастао човек, пише Игор Семјонович Кон, не може да се врати у напуштену земљу свог детињства. Истовремено, сваки одрастао човек носи у себи своје детињство, тачније, његово наслеђе у себи, и не може, чак ни када то жели, да га се ослободи (Kon, 1991: 94).

\section{4. Еманципаторске тенденције у делима педагошких класика}

Нова виђења и промене у односима према деци које је слутио Коменски, а одлучно формулисао Русо, створили су посебно наслеђе у историји педагогије у којем се „полази од детета“. Ера просветитељства иначе је била период у којем се тежило негирању дотадашње праксе и схватања опхођења са децом. Најодлучнији у том погледу био је Жан Жак Русо, чији утицај на педагоге није престао ни до наших дана. Према мишљењу Џона Дјуиа, Русоово поимање природе детета „садржи најдубље истине које су икад изречене о васпитању“. Једна од Русоових парадоксалних идеја надахњује нарочито заступнике тзв. негативног васпитања. Пошто је утврдио да је човек по природи добар, он у свом Емилу каже шта треба чинити да би се та „добра природа“ одржала, проширила и учврстила: „Без сумње врло много: спречити да нешто буде урађено. Почетно васпитање мора бити чисто негативно.“ Реч је, дакле, о обезбеђивању свих претпоставки за васпитање у складу са индивидуалним потребама детета које једино захваљујући „негативном васпитању“ могу да се испоље (Граорац, 1985: 56).

Покрет карактеристичан по томе што „полази од детета“ (vom Kinde aus) истакао је захтев за новим, другачијим и већим поштовањем детета, његових потреба, жеља, специфичних права и могућности. У писаним радовима Елен Кеј и Марије Монтесори, дете је проглашено субјектом који може неограничено да располаже самим собом. Истакнуто је да сваки поступак одраслих може бити препрека осамостаљивању детета. Васпитање мора поћи новим путем - путем ослобађања потенцијала. Наговештаји постпедагошког мишљења и искуства несумњиво и у највећој мери постоје у делима италијанске лекарке Марије Монтесори. Она је отпочела своју педагошку мисију критиком педагогије и васпитања у свом времену, разобличавањем врло конкретних суштинских предрасуда према деци и животу уопште. „На оно што се догодило са дететом“ - пише Марија Монтесори - „није утицала ниједна васпитно-обра- 
зовна метода. Управо, догодило се супротно: нове дечје особине, које су се постепено развијале, постале су наш водич и поучиле нас како да се опходимо са дететом“ (Montesori, 2003: 220). Полазити од детета - то искључује могућност да одрасли буду градитељи детета, у својим покушајима да дете обликују према својим претпоставкама и својим узорима. Дете је властити градитељ и стваралац - подвлачи Монтесори. Није човек творац детета. „Дете је творац човека. Нема човека кога није створило дете, оно дете које је он сам некада био“ (Montesori, 2003: 45).

Нема сумње да је Марија Монтесори своје кључне увиде у тајну детета стицала руковођена хришћанским надахнућем. Она назива дете врелом љубави: „Цео људски род дели дубока осећања која у њему изазива дете. Оно је врело љубави (...) Љубав те врсте тешко је објаснити. Свако је осетио њено дејство, али нико није у стању да опише њено порекло, оцени величину њеног утицаја нити разуме њено моћно уједињујуће деловање на људе“ (Montesori, 2003: 360). Пред крај свог главног теоријског дела (La Mente del Bambino; 1949. - „Дух детета“, код нас преведено као Упијајући ум), она изговара и објављује „неку врсту програма““ за васпитаче: „Помози нам, Боже, да проникнемо у тајну детета, како бисмо могли да га упознамо, заволимо и служимо му према законима Твоје правде и у складу с Твојом божанском вољом“ (Montesori, 2003: 357).

У историји европске културе нико није као Марија Монтесори озбиљно схватио новозаветну Христову поруку о деци. Она је препознала „древну несвесну погрешку целог човечанства“, „страшну слепоћу одраслих“ који се баве искључиво „преобраћањем детета“ и не примећују „непознату енергију детета“ која би могла читав свет уздићи на виши ниво (Montessori, 2003, 283). Стога, одрасли не треба да буду, не могу бити и све мање јесу узор дещи; него читаву ствар треба посматрати „више хришћански“, христоцентрично, педоцентрично, усредсређивањем на дете. Она је доживљавала и разумела дете као тајну. У „тајне детињства” могу се убројати сва она збивања, појаве и процеси у бићу детета и његовом понашању који још нису рефлектовани, нису спознати као такви а сматрају се значајним. Тајна прикрива моћ, снагу и потенцијал дететове „праве” природе. „Живети тајну детињства“ најпре значи - заједно са децом живети а не децу подучавати. Пошто је тајна скривена у несвесном детета и васпитача, могуће је да васпитачица живи тајну детињства а да то не зна. Не постоји школовани посматрач, „супервизор“ који то може проверити. Исидор Граорац објашњава да је овде реч о често расправљаном питању у педагогији: повезаности и/или јединству теорије и праксе. Сматрало се наиме да учитељ достиже врхунац успешности у свом раду, оживотворењем поменуте повезаности или јединства. Сложеност поменутог захтева произилази отуда што је у Монтесори педагогији реч о врло необичној теорији, а у дечјим кућама о особеној пракси. Овако проблем види ауторка Тајне детињства: Детету морамо помоћи да са̂мо дела, жели и мисли. То је умеће служења духу, умеће које се може усавршити једино онда када радимо (живимо) с децом... Проницањем у тајну детињства стиже се не само до дубљег знања него и до љубави сасвим посебне врсте. 
Марија Монтесори увек има у виду целовиту личност детета. Она конципира метод, образовање и педагогију мислећи на целину (тоталитет) животне ситуације детета (човека). Дете види у односу на васељену (,космичко васпитање“), у односу на Бога и с обзиром на смисао постојања (проблем, смрти, пролазности и вечности). Новији радови у Монтесори педагогији, иако се то изричито не каже, интерпретирају њено дело са становишта хуманистичке психологије. Отуда није тешко - тврди Исидор Граорац - да кренемо корак даље и у њеним радовима препознамо наговештаје нама савременог мишљења и искуства. На многим местима код Монтесори сусрећемо радикални став хуманистичке психологије, да дете треба прихватити онакво какво јесте (Граорац, 2002: 163). Она је захтевала да васпитач развије прихватање детета у дубљем смислу - да досегне стање празнине у којем нема посебних очекивања које би дете требало да испуни.

\section{5. Положај детета и одраслих у савременом свету}

„Родитељи и деца данас се заиста налазе у постмодерном стању. У таквој ситуацији не може се ништа значајно променити поправљањем односа са децом. Неопходна је коренита промена друштва, друштвеног система. Пресудни значај у објашњењу промена које се задњих деценија одигравају у структури, облику и функцијама породице многи аутори приписују процесу индивидуализације. Дакле, долази до слабљења осећања заједништва и индивидуалне разлике постају све значајније“ (Граорац, 2017: 155). У таквој ситуацији испоставило се да је неопходно редефинисати значења појмова васпитања и детета. Егзистенцијална ситуација савременог човека, нарасле противречности које оптерећују и угрожавају животе људи и опстанак човечанства је најопштији друштвени и вредносни оквир разматрања о васпитању. Не могу се занемарити већ четири или пет деценија и у нашој средини присутна сазнања о крају историје, смрти човека, упозорења на еколошку катастрофу, постмодернистичка искуства о обесмишљености постојања и зебњи пред неизвесношћу и, не на последњем месту, захтев за нихилистичким отрежњењем филозофије. Постмодерни теоретичари упорно доказују да је за педагогију најважније сазнање - да васпитање више није могуће. Велико је питање да ли је, уколико се полази са хуманистичког становишта, уопште могућа другачија, искуствено, теоријски и методолошки заснована педагошка теорија васпитања. Да ли је и како могуће - пита се Исидор Граорац - на другачијим аксиолошким и епистемолошким основама овде и данас заснивати педагогију? (Граорац, 1995а: 73).

Да ни васпитање неће избећи оштрицу постмодернистичког суда било је јасно још након критике технолошке рационалности, коју су спровели филозофи Франкфуртског круга. Догодило се нешто битно ново у положају човека и детета у 20. веку. Технолошка рационалност је препозната као тамна, скривена позадина васпитавања као сврсисходне делатности, али и као иманентно својство самог процеса који та делатност доводи до самог краја и обесмишља- 
ва. Као алтернатива инструменталном схваћено је и развијено комуникативно делање (Хабермас), које захтева другачије разумевање детета и васпитача, значења и улоге њиховог односа и размене са светом. То је једини начин суочавања са актуелним изазовима и негацијама смисла и вредности живота у свету. Историјско и свакодневно искуство употребе и злоупотребе моћи (власти, насиља, репресије) човека над човеком у различитим доменима живљења допринело је да се у 20. веку моћ човека над дететом радикално проблематизује (Сандо и Живковић, 2014: 174). При разматрању интеракције у светлу истраживања друштвене моћи постављена су следећа питања: врсте зависности, заснованост зависности и разлика у моћи, циљ и функције зависности и структура моћи, стварно дејство односа моћи. Трансформација моћи у право путем легализовања норми и вредности специфичних за једну групу постала је централни проблем друштвених наука. Показано је да се фактичко спровођење норми догађа путем присиле, понекад на симболичкој равни, као понашање сагласно очекивањима која су стандардизована, нормирана и санкционисана. Основни разлози због којих треба критиковати васпитање тичу се манипулације децом. Према постмодерним мислиоцима, она произилази из саме структуре васпитања као културно-историјског (цивилизацијског) процеса, нарочито од краја 17. века, када се оно институционализује и постаје делатност усмерена на обликовање деце, не будући саставни део њиховог живљења са одраслима. Данас не постоје легитимни, историјски, етички и друштвени разлози којима васпитачи могу оправдати манипулацију, јер не постоје вредности и стремљења друштва која они репрезентују, у име којих се може вршити „приморавање на слободу“ (Граорац, 1995: 172).

Још је Кант писао о васпитању као односу принуде легитимисане циљем, наиме, настојању да се средствима принуде дође до слободе. Средства су у сваком случају, била и остала централна педагошка тема. У педагогији се врло рано сазнаје о ненамераваним дејствима. Како пише Граорац, у историји педагогије разматрани су неки аспекти имплицитне педагогије у оквиру следећих тема: функционално васпитање, неплански утицаји, индиректна дејства, васпитање у ширем смислу и сл. Захтев да васпитач буде оно што јесте поставља се одлучно тек у хуманистичкој психологији и сродним дисциплинама. До тада су на снази била различита оправдања скривених намера васпитача. Битан део самог васпитања био је посвећен образовању маске, која преноси не оно што јесте већ оно што треба сматрати исправним (Граорац, 1995: 90-91). Овакав преокрет видан је и у мишљењу најсавременијих теоретичара педагогије, какав је Јеспер Јул. Реч васпитавати - тврди он - има двоструко значење: оно уобичајено, у смислу кориговати, опомињати, али и подизати, односно помоћи некоме да одрасте, припремати га за живот. „Да ли је васпитање једноставно однос? Да, однос би била добра реч ако наглашава равноправност родитеља и деце. Деца додуше на свет долазе с пуно мудрости, али премало искуства тако да им је потребно вођство одраслих. Деци је потребно вођство, али не оно које смо им досад нудили“" (Jul, 2020: 39). 


\section{Закључак: могући допринос хришћанске педагогије}

Већина противречности везаних за појам васпитања, којих је савремена педагогија у свету свесна, али не налази решење за њих, тиче се чињенице греха у људским односима, некакве друге природе коју та чињеница успоставља. Апостол Павле изражава темељни парадокс, тврдећи о себи да чини зло које не жели, а не чини добро, оно које жели. У Јеванђељу људи и њихове одлуке нису описани тако једноставно - могу се уочити сталне напетости између постојећих људских намера и стварног смисла односа који се одвија иза њих. Према Јеванђељу, „ко себе понижава узвисује се, а ко сам себе узвисује - тај се понижава“. Такође, „ко жели да сачува своју душу изгубиће је, а ко изгуби своју душу ради Христа и Јеванђеља - тај ће је сачувати“. Овај општеважећи парадокс јеванђеоских односа примењује се и када је реч о односу верних према деци, посебно када је реч о хришћанском васпитању. „Не називајте се учитељима између себе“ - ово значи да се духовно учење у хришћанству не заснива на ауторитету старијих и на потчињености млађих, већ пре на чињеници нашег заједничког учеништва у односу на Христа, нашег послушања Богу, као и на томе да поучавање није владање већ служење, Божје дело. Више од тога, одрасли у хришћанству позвани су да посматрају и уче од деце, прихватајући јеванђеоски идеал да буду као деца.

То није позив на одбацивање одговорности одраслих; напротив, то је једини могућ пут да очувамо ту одговорност. Ако се васпитање разуме као сврсисходна делатност, а педагогија као технологија утицања на дете, савремени хришћани дужни су да критички преиспитају такво схватање своје улоге. Христова љубав, оно што је њихова заповест и њихов пут, никада не може да се оствари као примена метода или као технологија, било да су у питању стари или нови, савремени методи. Оно за чим трага савремени свет нису нове теорије и нове методе васпитавања, већ нови односи са децом, за које хришћани верују да их је могуће остварити у Христовој љубави. Инсистирање на строгости васпитања, на ауторитету и патријархалној дисциплини у 21. веку, у савременој породици, савременој школи и савременом друштву, све више доводи заговорнике традиционалних схватања у трагичан положај, чинећи их губитницима који се окрећу против света и живота, бране неке застареле, превазиђене вредности, а занемарују непроцењиво благо које им нуди вера на коју се често позивају. Сведочити Христа могуће је идући у сусрет времену, а не покушавајући да се свет врати уназад.

Волети дете данас више него икада раније значи одазвати се душом, бити ту за њега, преузети у себи ризик да се подели неизвесност онога што долази. Таква мера присуства, то уживљавање и спремност на састрадавање са дететом, има веома мало везе са уобичајеним васпитним намерама одраслих. Када једном увиди стварну делотворност ових чинилаца, као и чињеницу да мењањем себе најдубље утиче на понашање свог детета, родитељ ће бити спреман да све оно што он мисли и што је намерио - па чак и када васпитава своју децу 
- потисне у други план. То је утолико лакше ако је свестан властите огреховљености, потребе да стално преиспитује и исправља све своје намере уопште.

Дете самостално ступа у ново време, пуно бескрајних могућности. У том смислу, његов начин изражавања важнији је од актуелних и друштвено признатих дискурса. Време у којем живе наше генерације суочило се са бурном пропашћу просветитељских нада. У добро уређеним политичким режимима 20. века испољила се запањујућа количина насиља човека према човеку. Био је то пораз не само политике већ и педагошких принципа хуманистичке традиције Запада. Свет се суочио са последицама необузданог испољавања моћи. То је нагнало мислиоце савременог доба да трагају за новим обрасцима афирмације, неговања и заштите људске личности. Актуелно време много озбиљније узима у обзир чињеницу греха, иако ту свесност изражава научним и философским терминима који нису потекли из хришћанске теологије. Уместо о греху, данас се више говори о отуђењу, растројености, солипсизму и различитим психолошким блокадама које спутавају развој човека. Потреба за поновним духовним утемељењем људских односа данас је широм света несумњива и неспорна. Поузданост самог човека и аутономног човечјег делања све више долази под знак питања, укључујући и саму педагогију онако како ју је разумео и доживљавао човек модерног света. Нико од људи није непогрешив - то је највеће сазнање савременог човечанства. Нису непогрешиви ни одрасли који брину о васпитавању себе и своје деце.

Ново етичко осмишљање педагогије захтева отворену концепцију и темељну критику њених технолошких и рационалистичких претпоставки, између осталих и са хришћанског становишта. Многи мисле да о васпитању и другим педагошким процесима није ни могуће мислити на другачији начин него што је то било својствено модерном добу - као о увођењу разума и реда. Претпоставља се да данашњи човек, говорећи о педагогији, има на уму једино то полазиште. У том случају решење педагошке кризе савременог доба можда и не треба тражити ни у каквим новим педагошким концепцијама или теоријама, већ у новим односима са децом, у којима вредности детињства неће бити грубо потчињаване нити подешаване према нормама света одраслих.

\section{Литература}

Амфилохије, М. (1993). Основи православног васпитања. Врњачка Бања: Братство Светог Симеона Мироточивог.

Arijes, F. (1989). Vekovi detinjstva. Beograd: Zavod za udžbenike i nastavna sredstva.

Буловић, Јеромонах Иринеј (1984). Христос и деца. Православни мисионар, 3/1984. 107-116.

Граорац, И. (1985). Русоово схватање улоге слободе и спонтаности у васпитању. Нaстава и васпитање, 1985/3. 115-131.

Граорац, И. (1995). Васпитање и комуникација. Нови Сад: Матица српска.

Граорац, И. (1995а). Смрт Бога, криза хуманизма и васпитање. У: Стеван Крњајић (ур.), Моралност и друштвена криза (205-228). Београд: Институт за педагошка истраживања. 
Граорац, И. (2002). Путеви ка Монтесори педагогији. У: Слободан Ђорђић (ур.), Зборник друштвено-хуманистичких наука бр. 2 (117-129). Бања Лука: Књижевна задруга Бања Лука.

Граорац, И. (2017). Родитељи и деца у перспективи народне, хришћанске и постмодерне педагогије. У: И. Граорац (прир.), Предшколска педагогија (147-158). Београд: Завод за уџбенике.

Живковић, И. (2011). Хришћанска етика. Београд: Свети архијерејски синод Српске православне цркве.

Jul, J. (2020). Od vaspitanja do odnosa. Autentični roditelji-kompetentna deca. Beograd: Harfa \& Pametnica.

Kon, I. S. (1991). Dete i kultura. Beograd: Zavod za udžbenike i nastavna sredstva.

Montesori, M. (2003). Upijajući um. Beograd: DN Centar.

Montessori, M. (2003). Dijete. Tajna djetinjstva. Zagreb: Naklada Slap.

Сандо, Д. и Живковић, И. (2014). Православна педагогија. Београд: Свети архијерејски синод Српске православне цркве.

\title{
CHRISTIAN EDUCATION AND THE MODERN PEDAGOGICAL THOUGHT
}

\author{
Ivica Živković \\ Centre for Church Studies, Niš
}

\begin{abstract}
Christian pedagogy is based in a specific pedagogical approach which, through all the historical periods, represents more than same possible new doctrine, new pedagogical theory or system of pedagogical comprehensions in the world. In this article we review Christian education by several most general principles, among which the most important are: the starting point of the faith in God, the specific relationship of love for child and the awareness of human sin. Furthermore we explore the opinion of some relevant researchers who claimed that the significance attributed to child in the history of pedagogical thought is related to the more profound penetration of Christian religion into the customs and perceptions of the Western world. The influence of Christianity is also apparent in the emancipatory tendencies of pedagogical classics, first of all in the attitudes of Maria Montessori, whose interpretation of Christ's words on children may be quoted as one of the greatest challenges for the contemporary understanding about the child issue. The status of child and grown-ups in the modern world imposes certain perplexities, and Christian pedagogy can propose some material contribution to their resolution.
\end{abstract}

Key words: Christianity, child, education, emancipatory tendencies, postmodern conditions.

\section{Citiranje članka:}

Živković, I. (2020). Hrišćansko vaspitanje i moderna pedagoška misao. Godišnjak za pedagogiju, 5(2), 21-33. 